\title{
オマーンにおける石油随伴水の性質と処理技術の開発
}

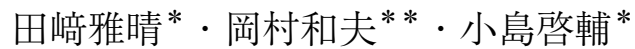

\section{Properties of oilfield produced water and development of treatment technologies}

\author{
Masaharu TASAKI*, Kazuo OKAMURA** and Keisuke KOJIMA*
}

\begin{abstract}
要旨
原油とともに汲上げられる地下水である石油随伴水は, オマーンのみならず産油国共通の最大量 の廃棄物であり, その殆どを莫大なエネルギーをかけ地中へ返送している。一方, 中東諸国では地下 水の枯渴, 塩害被害等の水資源確保が大きな問題となっている。そのためこの石油随伴水を新たな水 資源として利用できれば, 大きな環境問題を併せて解決することができる。特に中東のように気候や 労働条件が特殊な地域の場合, 現地ニーズを正確に掴み, 先方の希望するシステムを実現することが 重要となる。ニーズに沿った随伴水処理システムを開発し, その処理水の利用の可能性を示すこと は, 当該国の目指す持続可能産業の創出に大きく貢献できるものとなる。
\end{abstract}

キーワード : 石油随伴水, 油分除去, 凝集, 滤過処理, 吸着処理, 処理水利用, 灌溉

\section{1.はじめに}

石油随伴水は，単に随伴水，あるいは，石油同 伴水などとも言われ，原油とともに生産される地 下水を指す (図 1 参照)。その水量は一般に原油 掘削量の 3 6 倍量と言われ, 油田が古いほど水 量は多くなってくる (Fakhru'sl-Razi et al., 2009; Ebenezer et al., 2012)。また, 独立行政法人石油 天然ガス・金属鉱物資源機構（JOGMEC）（2014） によると2011年時点の陸上での石油随伴水生産量 は 1 日あたり 2 億4100万バレルであったのに対し て，2015年では，1日あたり 2 億6500万バレルと 増加して打り, 今後も増加傾向にある推測されて
いる。このため石油随伴水は産油国共通の最大量 の廃棄物と言われている。

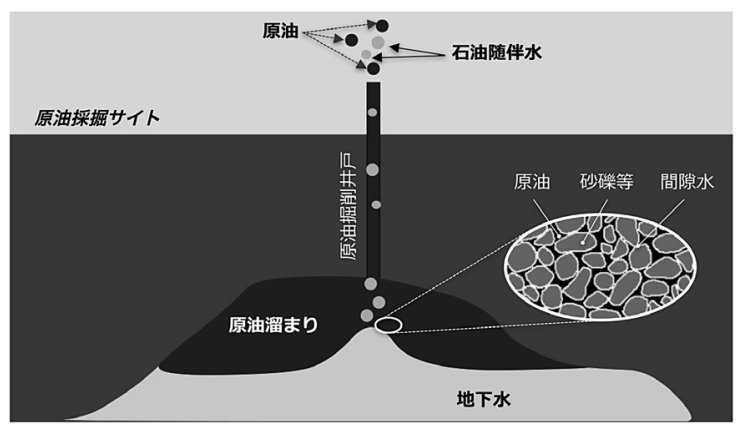

図 1 石油随伴水の原理概念図

* 清水建設株式会社 技術研究所（广135-8530 東京都江東区越中島三丁目4番17号）

Shimizu Corporetion

** 株式会社トッププランニング JAPAN

Top Planning Japan Co., Ltd 
オマーンにおいては, 原油 1 に対して石油随 伴水量が 8 10と膨大な量の随伴水を排出して いる油井もある（Al-Bemani et al., 2001; Asada et al., 2007)。現在, 最大の随伴水を排出している油 田には, 一日20万 $\mathrm{m}^{3}$ 以上の随伴水が排出されて おり, この量は首都マスカットの一日の上水使 用量に匹敵する（岡村ほか, 2011 ; 田崎ほか, 2013b)。

オマーンにおける石油随伴水の処理は, 一部浮 上法による油分除去を行っている油田があるもの の, その多くは浄化と言う観点ではなく油の回収 を経済的に行う目的で, 重力利用の単純な油水分 離システムを採用している。汲上げられた原油 はヒーターで暖められて油がスキミングされ石 油随伴水と分離され, 更に石油随伴水は CPI セ パレーターなどの単純な装置によって残りの油 分が回収される。その後, この石油随伴水は地 下に返送されている。しかし，Fakhru'sl-Razi et al. (2009) では石油随伴水に含まれる油分には 油分粒径が $10 \mu \mathrm{m}$ 以下とエマルジョン化した微細 な油滴が存在するために, CPI セパレーターに よる油水分離処理では完全に除去できず，平均 $250 \mathrm{mg} / \mathrm{L}$ の油分が残存していると言われている。

オマーン北部の油田の場合, 原油掘削に伴う带 油層の圧力低下の防止のために石油随伴水は全て 帯油層に再注入されている。一方南部の場合は,

こうした圧力低下がないため, 帯油層より浅い地 下水層に廃棄されてきた（岡村ほか, 2011; 田崎· 岡村, 2012)。しかし, 生活用水を地下水に依存 している同国では，これら地下水脈に油分が混入 する危険性があるために, 法令で浅層部への返送 が禁止された。それを受けて各油田サイトは油層 の上下に存在する深部の地下水層に注入するため の水処理方法の確立を1995年からの五力年計画 で目指した。哚部の地下水層は地下 $1200 \sim 1500 \mathrm{~m}$ に存在し, 石油随伴水処理水を注入するためには 高出力のポンプで水を押し込む必要がある。しか し, 長期的には飽和圧力の上昇, 油分による帯水 層の閉塞等から注入に問題を生じる可能性が懸念 され，処理水質レベルの向上が求められている。

また, 石油随伴水の水質は油井サイトにより異 なる。特に塩分濃度や硬度に差が大きく, 高いと ころでは塩分濃度 $20 \%$ 以上, Ca 濃度 $10,000 \mathrm{mg} / \mathrm{L}$
以上の石油随伴水が発生するサイトもある（次 章参照)。さらに昨今, 石油増進回収 (Enhanced Oil Recovery；以下 EOR）技術の一つであるポリ マー圧入法の適用により, 石油随伴水水質は従来 の石油随伴水とは異なってきている(次章参照)。 そのため石油随伴水処理技術には様々な水質にも 対応できる様な汎用性のあるシステムが求められ てきている。

石油随伴水はその水量が膨大であるために, 一 般的な工場廃水の処理技術よりも格段に簡易で低 コストの処理技術が要求され, 既存技術の適用は 困難である。また, 厳しい気候条件や実質労働者 の能力等の制限もあり複雑なシステムやデリケー 卜な装置等を使用することに大きな制限が掛かっ ている。すなわち「簡易で汎用的な処理技術」を 確立する必要がある。

このようなオマーン側のニーズを背景に筆者ら は「簡易で汎用性のある高効率な処理システム」 の開発を目指してきた。

\section{2. オマーンの石油随伴水の特長}

一概に石油随伴水と言っても, その水質は地域 により大きく異なっている。原油と供に汲上げら れるためにその地下水は化石水であることも少な くなく, 塩分濃度が著しく高い場合もある。才 マーンの場合, 北部の油田ほど塩分濃度が高く なる傾向があり, ある北部の油田では飽和濃度 に近い塩分濃度 $23.4 \%$ を示す石油随伴水も存在す る。筆者らが実際に分析したオマーン各サイトの 石油随伴水の主な水質を表 1 に示した（田崎ほ か, 2013a)。この表からも解るようにカルシウム (Ca) 等のミネラル分も高濃度を示しているサイ トが存在している。高濃度ミネラル成分の存在 は，配管等の設備へのスケール付着などの障害を 引き起こす要因となる。

また，石油随伴水に含有する油分もサイトによ りその性状が異なり，オマーンにおいては南部油 田の原油は重質油が多いといわれている。表 1 に 示したサイトの中の 4 サイトの石油随伴水中の油 分（原油）と一般的な $\mathrm{C}$ 重油について, その油 分を構成する炭化水素の炭素数別の存在比率（炭 素数組成 (\%)）を測定した結果を図 2 に示した。 
オマーンのサイトにおける油分の炭素数は15から 30程度の炭化水素を主体としているが，サイトA や F では炭素数10以下の軽い炭化水素も多く存 在している。また，C重油同様に炭素数40を超え る油分を含む重質油系の油分を含むサイト B な ど，地域により油種が異なることが解る。

また, 最近では効率的な原油回収のために EOR 技術が適用されてきている。濱田（2013） の報告によると, 当初オマーンで適用された EOR 技術は，蒸気や天然ガスを注入する方法で あった。しかし, 国内での天然ガス不足や地下水 枯渇の懸念などからケミカル圧入法や $\mathrm{CO}_{2}$ 注入法 などへのシフトが検討されてきた。特に増粘剤 であるポリマーなどを用いたケミカル圧入法を 適用した油田から産出した石油随伴水 (Polymer
Flood Produced Water：以下 PFPW）が従来の石 油随伴水と異なる水質を示し, 随伴水中の油滴の エマルジョン安定性が進んでいることなどが Ma et al. (2013) で報告されている。

\section{3. 石油随伴水の処理技術の開発}

石油随伴水は前記したようにその発生量が膨大 であるために，製油所等の工業廃水処理のような 既存の施設の適用は困難である。また, 中東諸国 ではその過酷な気象条件から, 熱や埃に弱い精密 な設備の使用が制限され，さらに近隣諸国からの ワーカーがプラントの運転を担当するため, 作業 者能力の制約も生じる。従って現地の石油会社か らも，「高度な技術を用いた複雑な装置」よりも，

表 1 オマーン各サイトの石油随伴水の水質

\begin{tabular}{ccccccccc}
\hline & $\begin{array}{c}\text { salinity } \\
(\%)\end{array}$ & $\begin{array}{c}\text { CODMn } \\
(\mathrm{mg} / \mathrm{L})\end{array}$ & $\begin{array}{c}\text { CODCr } \\
(\mathrm{mg} / \mathrm{L})\end{array}$ & $\begin{array}{c}\text { TOC } \\
(\mathrm{mg} / \mathrm{L})\end{array}$ & $\begin{array}{c}\text { Oil } \\
(\mathrm{mg} / \mathrm{L})\end{array}$ & $\begin{array}{c}\mathrm{Ca} \\
(\mathrm{mg} / \mathrm{L})\end{array}$ & $\begin{array}{c}\mathrm{Mg} \\
(\mathrm{mg} / \mathrm{L})\end{array}$ & $\begin{array}{c}\mathrm{Cl} \\
(\mathrm{mg} / \mathrm{L})\end{array}$ \\
\hline site-A & 0.42 & 23 & 81 & 36.9 & 28 & 40.0 & 19.5 & 1,900 \\
\hline site-B & 0.44 & 57 & 140 & 65.0 & 37 & 24.4 & 7.9 & 2,100 \\
\hline site-C & 0.70 & 7.2 & 69 & 3.9 & 10 & 116 & 37.7 & 3,800 \\
\hline site-D & 0.76 & 6.5 & 41 & 1.9 & 3 & 100 & 31.0 & 4,000 \\
\hline site-E & 0.98 & 8.5 & 48 & 9.8 & 19 & 126 & 46.9 & 2,000 \\
\hline site-F & 1.07 & 9.6 & 98 & 7.2 & 17 & 136 & 43.4 & 6,000 \\
\hline site-G & 2.03 & 13 & 220 & 16.0 & 16 & 481 & 145 & 14,000 \\
\hline site-H & 2.59 & 34 & 300 & 17.0 & 15 & 579 & 175 & 18,000 \\
\hline site-I & 15.6 & 18 & - & 2.4 & 41 & 11,000 & 2,600 & 130,000 \\
\hline site-J & 18.2 & 19 & - & 5.0 & 36 & 14,000 & 2,100 & 150,000 \\
\hline site-K & 23.4 & 57 & - & 77.0 & 18 & 17,000 & 2,700 & 200,000 \\
\hline
\end{tabular}

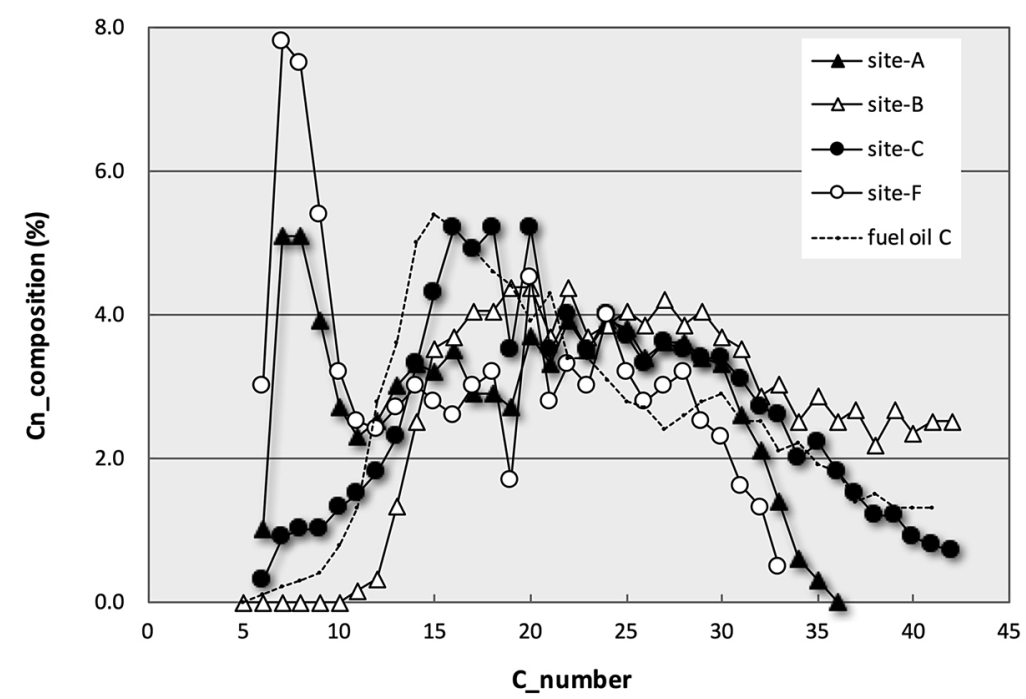

図 2 各サイトの随伴水に含まれる油分の炭素数組成

(分析は ASTM D 2887 に準じたガスクロマトグラフ蒸留法に従い, 油分 を構成する各炭素数別（横軸）の存在比率（縦軸）を示す。） 
「簡易でかつ汎用性と効率の高い処理システム」 が求められてきた。

これら現地ニーズを満足し，さらにオマーン国 内に点在する大小合せて150力所以上の原油生産 サイトの異なる随伴水水質にも柔軟に適合出来る 処理システムの構築が必要であった。

\section{1 開発された処理システムの概要とパイ ロットプラント}

前記した背景をもとに，処理システムが検討さ れてきたが，筆者らが開発し現地にて実証試験を 行った処理システムを紹介する。この処理システ 厶の基本的処理方法は凝集浮上分離である。石油 随伴水に分散して存在するエマルジョン化して水 と分離し難い数〜数十 $\mu \mathrm{m}$ の微細な油分粒子を, 凝集剤を添加することにより $5 \mathrm{~mm}$ 大の塊に凝集 させ，この油分塊をマイクロバブル技術によって 浮上させて効率よく除去する。このシステムは, 既存の凝集浮上分離システムにマイクロバブル技 術を付加したもので，マイクロバブルが水中の浮 遊物質に付着し浮上させる特性を利用している。 通常の浮上処理は加圧浮上装置や圧力容器などの 設備を用いるが，本処理システムでは必要としな い。これは中東の気象条件, 労働者の能力, 及び 随伴水の水質に対応するために改良したものであ る（田崎ほか, 2013b)。
開発した石油随伴水処理システムの基本フロー を図 3 に示した。本システムでは中東での稼働を 考慮して, 砂漠地带での使用や, 人気のない場所 での昼夜連続連転など，極力保守管理が低減され るシステムにする必要があり, 特に日中の高温に よる制御回路，センサー，ポンプ等への影響を充 分考慮した仕様としている。特に制御回路は熱の 影響を顕著に受けるために，回路を設置した制御 盤は冷房設備を設置したコントロール室を作り， その中に収めた。また, 本システムは多様な随伴 水水質に対しても基本となる処理フローであり,

各サイト別に最適な運転条件（供給量, 凝集剂種 及び添加量, 滤過速度, 吸着速度等) を設定し運 転することができる。また，各サイトで必要に応 じて処理工程（曝気による脱硫, $\mathrm{pH}$ 調整, 金属 除去等）を付加することが出来る仕様になってい る。

このシステムでは, マイクロバブルポンプ への送気は空気ではなくPSA (Pressure Swing Adsorption）方式の窒素ガス発生装置により生成 された窒素ガスを用いている。これは実際に設置 する生産プラントにおいて, その後の設備やパイ プライン等への影響（酸化や防爆等）を考慮した ものである。

図 3 に示したフローに従い, 実証処理試験のた めのパイロットプラントを製造した。製造したパ

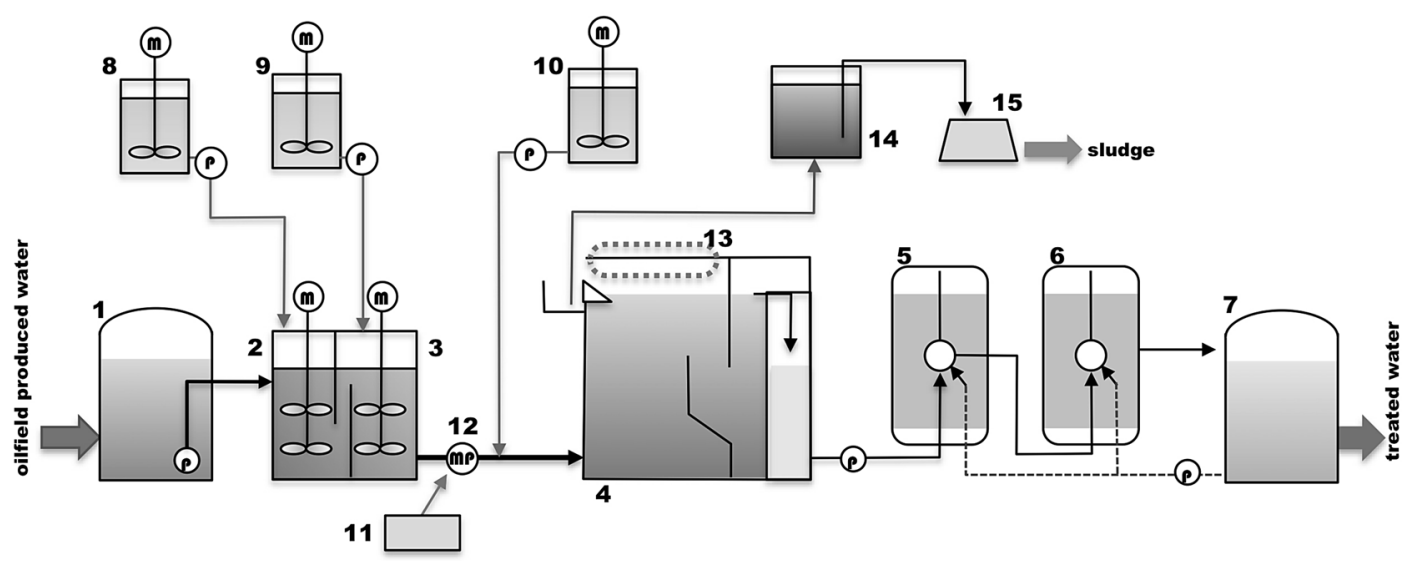

図 3 開発した石油随伴水処理システムの基本フロー

$1:$ 原水タンク $\left(20 \mathrm{~m}^{3}\right), 2:$ 凝集タンクー $1\left(0.4 \mathrm{~m}^{3}\right), 3:$ 凝集タンクー $2\left(0.4 \mathrm{~m}^{3}\right), 4:$ 浮上槽 $\left(1.4 \mathrm{~m}^{3}\right)$, $5:$ 濾過塔 $\left(0.4 \mathrm{~m}^{3}\right), 6:$ 吸着塔 $\left(0.4 \mathrm{~m}^{3}\right), 7:$ 処理水タンク $\left(4 \mathrm{~m}^{3}\right), 8:$ 凝集剤タンク (200L), $9:$ 予備 薬品タンク (200L), 10 : 高分子凝集剤タンク $\left(1 \mathrm{~m}^{3}\right), 11: \mathrm{PSA}, 12:$ マイクロバブルポンプ, $13:$ レー キ, $14:$ スカムタンク, $15:$ スカム脱水機. 
イロットプラントの処理システム全体での設計処 理水量は最高 $2 \mathrm{~m}^{3} / \mathrm{hrs}\left(48 \mathrm{~m}^{3} / \mathrm{day}\right)$, アンスラサイ トが充填された滤過塔は最大 LV（線速度：流体 がろ過タンク断面を通過する速度）を $5.2 \mathrm{~m} / \mathrm{hr}$, 活性炭が充填された高次処理用吸着塔は最大 SV (空間速度：ろ過タンク内のろ材を通過する速度） を6.7/hrである。写真 1 に現地石油サイトに設置 したパイロットプラントの様子を示した。

\section{2 開発システムによる石油随伴水の処理}

前記パイロットプラントを用いて, 幾つかの実 際のサイトからの石油随伴水による連続実証処理 を行い，その性能を検証した。

図 4 は本システムの設計水質としたサイト -1 での処理状況を示したグラフである。通常の水 処理と同様に，事前に運転条件設定試験により 凝集剤（ポリ塩化アルミニウム； poly aluminum chloride, 以下 PAC) 濃度等を設定し, 連続処理 を行う。

このシステムの処理フローは「原水 $(\mathrm{RW})$ - 窒 素ガス凝集浮上処理 $(\mathrm{NF})$ - アンスラサイト濾過 処理 $(\mathrm{AF})$ - 活性炭吸着処理 (AC)」(カッコ内 の記号は図中の記号に合致する) である。マイク ロバブルによる凝集浮上処理により石油随伴水に 含まれていた油分はほぼ除去され，同時に濁度も 除去される（田崎ほか, 2013b)。凝集分離後の SS (浮遊物質濃度) は凝集効果により若干上昇 するが, アンスラサイト滤過処理により完全に除 去される。図 4 において活性炭吸着処理後 (吸着 塔出口）のSSがアンスラサイト濾過後より若干 上昇しているが，これは連続処理過程で活性炭出 口側表面や配管等に析出付着していた成分が，サ ンプルのタイミングで剥がれて流出し, SS とし

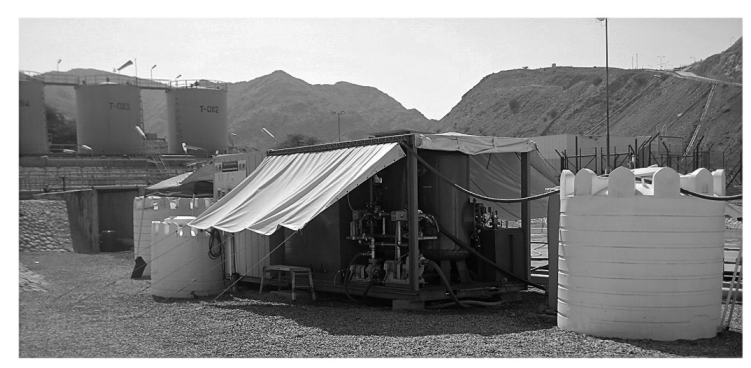

写真 1 実際の現地石油サイトに設置したパイロットプラ ントの概要
て測定されたためと考えられた。

油分が浮上分離処理により除去されると同時に その分の油分由来の COD 值が低下しているが, それ以外の COD 成分は滤過処理後もほとんど変 わりがないことより, 溶解性 COD であると考え られる。この溶解性 COD 成分は活性炭吸着処理 により除去される。

石油随伴水に硫黄化合物が混じることはその油 井サイトの特徵から多々見られる。この石油随伴 水に含まれている硫化水素やメチルメルカプタン はその臭気のみならず, 処理後における腐食性や 酸化物による濁度の上昇等の障害が懸念される。 そのためこのような硫黄化合物を含有する石油随 伴水処理のためには, 凝集浮上処理後に曝気処理 工程を付加し, 水中からの揮発除去及び強制的に 酸化物を生成させて, 後段の濾過処理で除去工程 を行う。すなわち処理フローは「原水 $(\mathrm{RW})$ - 窒 素ガス凝集浮上処理 $(\mathrm{NF})$ - 曝気処理 $(\mathrm{AR})-$ ア ンスラサイト滤過処理 $(\mathrm{AF})$ - 活性炭吸着処理 (AC)」である。

硫黄化合物を含む石油随伴水を生産している サイト-2にて行った処理試験結果を図 5 に示し た。油分は凝集浮上処理によりほとんど除去され る。SSが凝集浮上処理及びエアレーションによ り上昇しているが，これは石油随伴水中の油分及 び油分以外の濁度成分となっている溶解性物質が 凝集操作とエアレーションによる酸化作用により 析出しフロックとして生じたためである。濁度は 濾過処理により完全に除去され, 濾過で除去でき ない溶解性の COD 成分は活性炭による吸着処理

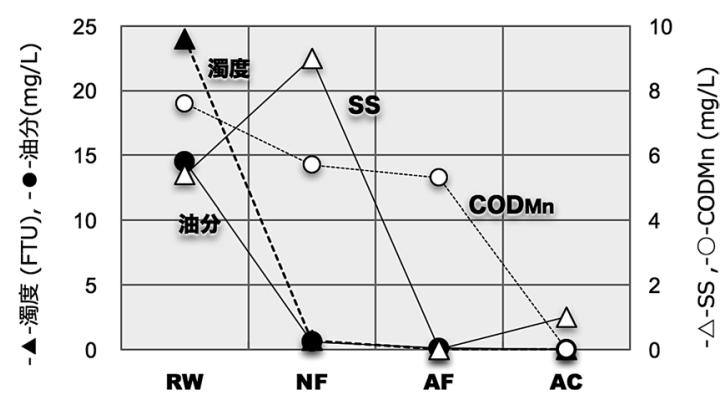

図 4 サイト -1 石油随伴水の連続処理試験における各処 理段階での水質の推移

$\mathrm{RW}$; 原水, NF ; 窒素ガス凝集浮上処理, $\mathrm{AF}$; ア ンスラサイト濾過処理, AC ; 活性炭吸着処理 
により除去される。硫黄化合物は浮上槽内での窒 素ガスマイクロバブルによる揮発促進も期待され ていたが，本試験運転においては，現状での気液 比では随伴水中の全ての硫黄化合物を除去するこ とが出来ず，その後のエアレーションにより全て の硫黄化合物が除去された（田崎ほか，2013b）。

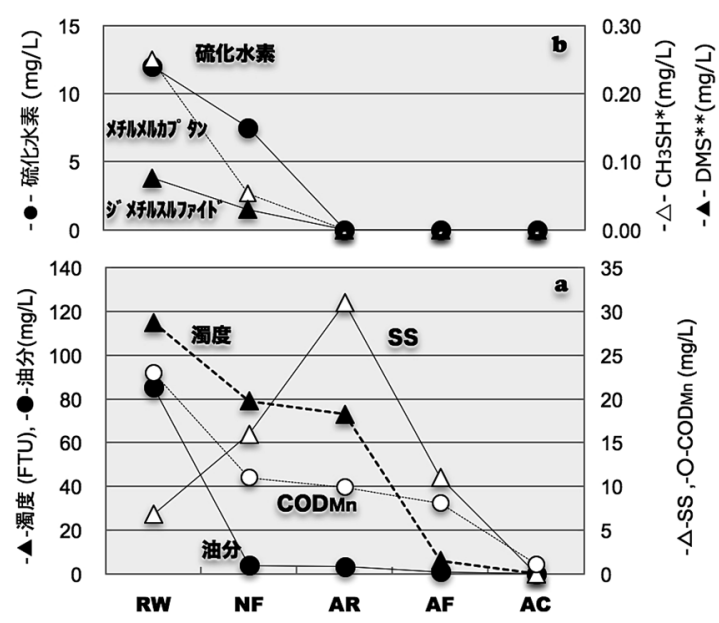

図 5 サイト -2 石油随伴水の連続処理試験における各処 理段階での水質の推移

$\mathrm{RW}$; 原水, NF; 窒素ガス凝集浮上処理, $\mathrm{AR}$; エアレー ション, AF ; アンスラサイト濾過処理, AC ; 活性 炭吸着処理

$\mathrm{a}$ : 濁度, 油分, SS, CODMn, b : 硫化水素, *メ チルメルカプタン, **ジメチルスルフィド
前記したようにオマーンにおいてもポリマー圧 入法により増粘剤を導入されている油田が増えて きている。この増粘版を含有している PFPWに は, 通常の凝集剂の効果が低いことが知られて いる。増粘剤が混入していないサイト-1やサイ ト-2においては, 凝集浮上処理の際の凝集剤に はPACが有効であるが, PFPWにおいてはPAC よりも硫酸バンド (aluminum sulfate：以下 AS と記す）が効果的である。写真 2 に増粘片を導 入しているサイト -3の随伴水 (PFPW) につい て PACと ASによる凝集比較を行った様子を示 した。この図から解るように増粘剤が随伴水に混 入することにより, PACの効果が低減する。こ の効果低減は, 単なる $\mathrm{pH}$ やアルカリ度の上昇に よるものではなく，随伴水が含んでいる無機炭酸 と増粘剤との相互作用により現れている（小島ほ か, 2015)。

サイト-3の PFPW の処理試験の結果を図 6 に 示した。また, この PFPW は, 前処理としての CPI セパレーターを通っていない未処理の随伴水 であるため, 非常に油分濃度が高い。そのため油 分濃度がパイロットプラント設計值を超えており 基本の凝集浮上処理では除去しきれない。未除去 の油分は, 理論的には次段階のアンスラサイト濾 過処理により除去することは可能であるが, 滤 過処理への負担を軽減するために, 基本フローに

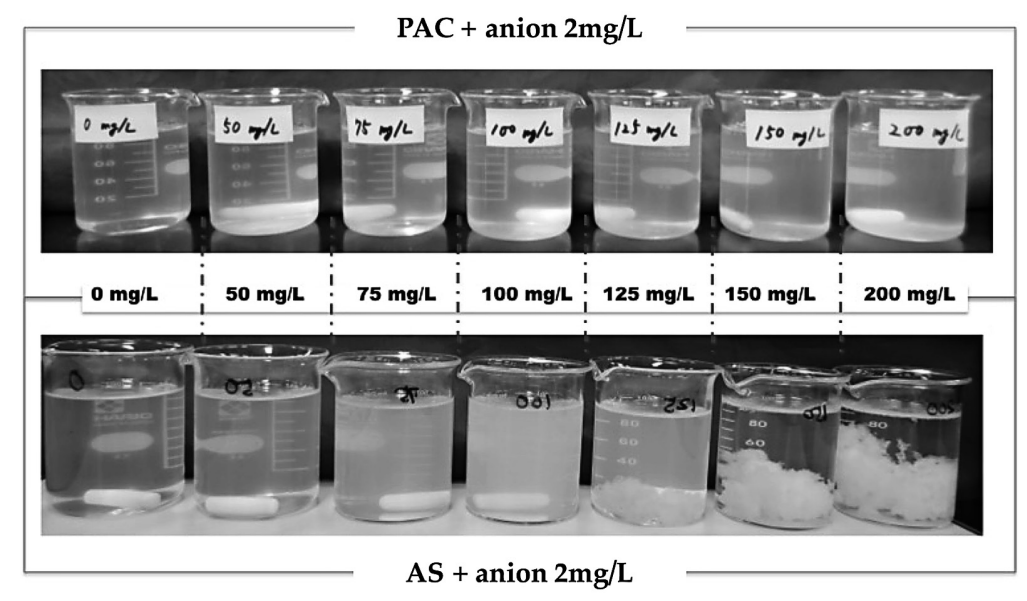

写真 2 PFPW におけるポリ塩化アルミニウム（PAC）と硫酸バンド（AS）に よる凝集効果の違い

上:ポリ塩化アルミニウム, 下: 硫酸バンド。凝集促進剤としてアニ オン系高分子凝集㓮を各 $2 \mathrm{mg} / \mathrm{L}$ 添加 
二次凝集処理を付加した。すなわち処理フローは 「原水 $(\mathrm{RW})$ - 窒素ガス凝集浮上処理 $(\mathrm{NF})$ - 二次 凝集処理 $(2 \mathrm{~F})$ - アンスラサイト滤過処理 $(\mathrm{AF})$ 活性炭吸着処理 $(\mathrm{AC}) 」$ である。

原水（RW）中の油分及び濁度は，窒素ガス凝 集浮上分離処理 (NF) 及び二次凝集処理 $(2 \mathrm{~F})$ によりほほ全て除去された。また，同様に濁度も 90\%が除去された。これに対して COD は最初の $\mathrm{NF}$ により40\%が除去されたものの，アンスラサ イト滤過処理 $(\mathrm{AF})$ 後までその值は変化がなかっ た。活性炭吸着処理（AC）によりほほ除去され ていたことより，この COD 成分はSS 由来では なく溶解性の物質であることが解る（小島ほか, 2015)。

このように EOR 技術が適用され増粘剤が混在 している石油随伴水で, さらに油分濃度が高くと も，効果的な処理工程を組み合わせることによ り，良好な処理が可能であることを示せている。

この一連の石油随伴水処理により発生する廃棄

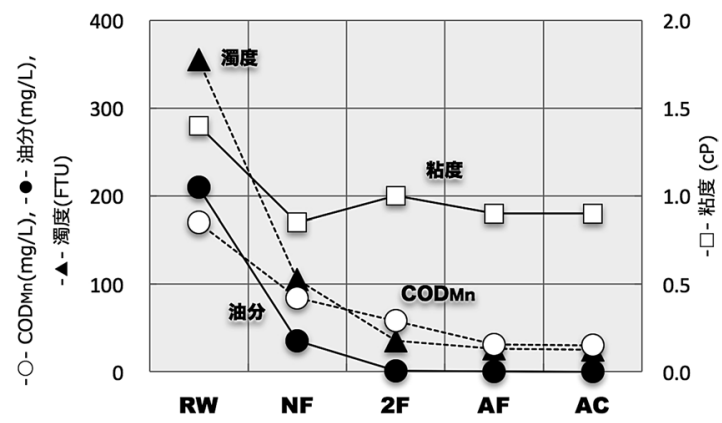

図 6 サイト-3 石油随伴水の連続処理試験における各処 理段階での水質の推移

$\mathrm{RW}$; 原水, NF ; 窒素ガス凝集浮上処理, $2 \mathrm{~F}$; 二 次凝集処理, AF ; アンスラサイト濾過処理, AC ; 活性炭吸着処理
物は，凝集浮上処理により分離された凝集油分で あるスカムである。当然ながら廃棄物は少なけれ ば少ないほど環境的にも経済的にも有利である。

本システムではそのスカムを多重円板外胴型スク リュープレス方式の脱水機を用いることにより 減量化を図っている (写真 3 参照)。また, サイ ト-1及びサイト - 2での連続試験の際に発生した スカムの処理結果を表 2 に示した（田崎ほか, 2013b）。凝集浮上処理により発生するスカムは 原姿で処理総水量の $1 \sim 2 \%$ に相当している。こ のスカムは脱水機により体積で $0.05 \sim 0.1 \%$ 程度ま で濃縮された脱水ケーキとなる。更に中東の地域 的特長を活かして，この脱水ケーキを強い太陽 光による天日乾燥にかけると，最終的に0.005〜 $0.01 \%$ にまで減容することも可能である。

\section{4. 石油随伴水処理水の水質と利用の可能性}

オマーンをはじめ中東の産油国では地下水の枯 渴，塩害被害等が大きな問題となっている。その

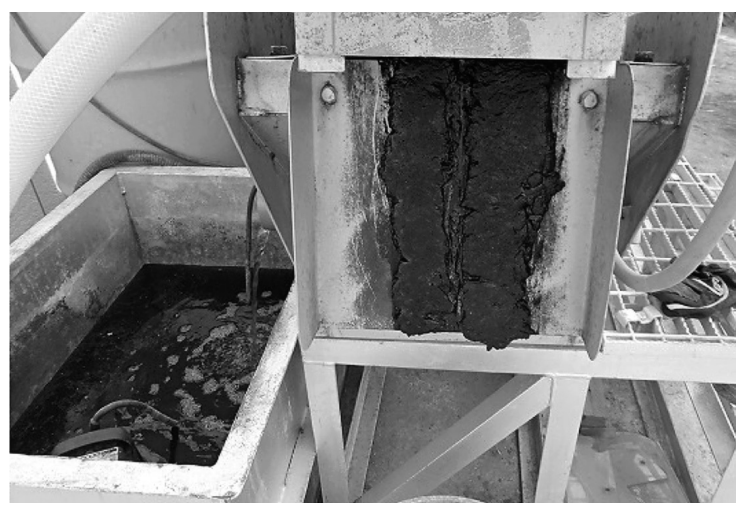

写真 3 スカムからの多重円板外胴型スクリュープレスに よる脱水ケーキの生成

表 2 発生スカムの脱水

\begin{tabular}{|c|c|c|c|c|c|c|}
\hline & & & $\mathrm{PW}^{*}$ & scum & $\mathrm{DW}^{* *}$ & $\mathrm{SDC}^{* * *}$ \\
\hline \multirow{2}{*}{ Site-1 } & volume & $\mathrm{m}^{3}$ & 20 & 0.2 & 0.009 & 0.001 \\
\hline & incidence $^{* * * *}$ & $\%$ & 100 & 1.0 & 0.045 & 0.005 \\
\hline \multirow{2}{*}{ Site-2 } & volume & $\mathrm{m}^{3}$ & 15 & 0.3 & 0.015 & 0.002 \\
\hline & incidence & $\%$ & 100 & 1.8 & 0.100 & 0.011 \\
\hline
\end{tabular}


ためこの石油随伴水を新たな水資源として利用で きれば，水不足という大きな環境問題を併せて解 決することができる。

今回紹介した処理試験でのサイト -1の原水（石 油随伴水) とその処理水（凝集処理後及び吸着処 理後）の水質を表 3 に示した。また，高次処理と してRO（逆浸透膜濾過）処理を行った場合の数 值を，オマーンの再利用水の水質基準とともに併 記した（小島ほか，2015）。この表からも明らか なように，本来の目的である石油随伴水の油分処 理の観点からは吸着処理までの基本フローで充分 にその目的を達成できる。しかし，処理水の再利 用を考えた場合，決められた水質にまで更に処理 を行う必要がある。例えば，処理水を灌溉に利用 するためには，表に併記した「灌洦利用のための 水質基準」を満足させる必要がある。オマーンの 石油随伴水は，前記したように多少なりとも塩分 を含む場合が多く，サイト-1においても $0.4 \%$ 程 度の塩分を含んでいる。そのため，まずはこの塩 分除去を目的とした RO 処理を行う。これにより 処理水中の塩分は灌溉水として満足する濃度を確 保できる。しかし，このサイト-1の場合のよう
に，随伴水にはホウ素が含まれることが多い。こ のホウ素は単純な $\mathrm{RO}$ 処理では除去しきれないた め, 再度 $\mathrm{RO}$ 処理を行う二段 $\mathrm{RO}$ 除去により対応 する。表に示されるように，RO 供給水のホウ素 濃度 $4.6 \mathrm{mg} / \mathrm{L}$ が，一次 $\mathrm{RO}$ 処理により $2.7 \mathrm{mg} / \mathrm{L}$

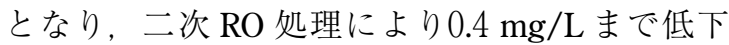
し, 生食用野菜に使用する場合に適用される灌溉 用基準 Aの0.5 mg/L を下回っている。

灌溉利用可能となる基本処理フローから 2 段 $\mathrm{RO}$ 処理まで行った場合, 同サイトの石油随伴水 の処理コスト（ランニングコスト）は 17.69 円 $/ \mathrm{m}^{3}$ と計算されている（小島ほか, 2015）。仮にこの コストをかけて随伴水処理水を利用した場合，こ れまで単に地下に返送していた際の返送コストを 削減できることになる。中東諸国の油田サイトで はその詳細な地下返送コストを明らかしていな いが, Bauer 社が行っているオマーンの Nimr 油 発掘サイトでの報告 (Breuer, 2011) や Breuer and Grissemann（2011）を参考にすると21.6〜 33.0 円 $/ \mathrm{m}^{3}$ と試算される.実際はそれぞれ建設コ ストや維持管理等が加算されるために単純比較は できないものの，随伴水処理水の灌賄利用の可能

表 3 石油随伴水処理水の水質とオマーンにおける灌漑利用及び飲料水にかかわる基準値

\begin{tabular}{|c|c|c|c|c|c|c|c|c|c|}
\hline & & \multirow{2}{*}{ 原水 } & \multirow{2}{*}{ 凝集処理水 } & \multirow{2}{*}{ 吸着処理水 } & \multirow{2}{*}{$\begin{array}{l}\text { 第一RO処理 } \\
\text { (脱塩処理) }\end{array}$} & \multirow{2}{*}{$\begin{array}{l}\text { 第二RO処理 } \\
\text { (木门素処理) }\end{array}$} & \multicolumn{2}{|c|}{ 再利用水の潅溉用基準* } & \multirow{2}{*}{ 飲料水基準 } \\
\hline & & & & & & & A & $B$ & \\
\hline 油分 & $\mathrm{mg} / \mathrm{L}$ & 14.5 & 0.6 & $<1.0$ & & & 0.5 & 0.5 & - \\
\hline 濁度 & FTU & 24.0 & 0.7 & $<1.0$ & & & - & - & 1 \\
\hline SS & $\mathrm{mg} / \mathrm{L}$ & 5.4 & 9.0 & $<1.0$ & & & 15 & 30 & - \\
\hline 塩素イオン & $\mathrm{mg} / \mathrm{L}$ & 3,760 & 3,240 & 3,390 & 134 & 2.8 & 650 & 650 & 600 \\
\hline 硫酸イオン & $\mathrm{mg} / \mathrm{L}$ & 357 & 324 & 337 & 4.6 & 0.04 & 400 & 400 & 400 \\
\hline ナトリウムイオン & $\mathrm{mg} / \mathrm{L}$ & 2,820 & 2,560 & 2,650 & 92.2 & 1.9 & 200 & 200 & 400 \\
\hline マグネシウム & $\mathrm{mg} / \mathrm{L}$ & 36.9 & 33.8 & 35.0 & 0.35 & $<0.01$ & 150 & 150 & 150 \\
\hline マンガン & $\mathrm{mg} / \mathrm{L}$ & 0.20 & 0.03 & 0.19 & $<0.01$ & $<0.01$ & 0.1 & 0.5 & 0.4 \\
\hline 木ウ素 & $\mathrm{mg} / \mathrm{L}$ & 4.9 & 4.7 & 4.6 & 2.7 & 0.4 & 0.5 & 2.4 & 0.5 \\
\hline ふつ素 & $\mathrm{mg} / \mathrm{L}$ & 2.6 & 1.9 & 1.6 & & & 1 & 2 & 2 \\
\hline バリウム & $\mathrm{mg} / \mathrm{L}$ & 0.10 & 0.08 & 0.38 & & & 1 & 2 & 1 \\
\hline リチウム & $\mathrm{mg} / \mathrm{L}$ & 0.12 & 0.12 & 0.12 & 0.02 & 0.01 & 0.07 & 0.07 & - \\
\hline P非决 & $\mathrm{mg} / \mathrm{L}$ & $<0.1$ & $<0.1$ & $<0.1$ & & & 5 & 5 & 0.2 \\
\hline 銅 & $\mathrm{mg} / \mathrm{L}$ & $<0.01$ & $<0.01$ & $<0.01$ & & & 0.5 & 1 & 2 \\
\hline 亜鉛 & $\mathrm{mg} / \mathrm{L}$ & $<0.01$ & $<0.01$ & $<0.01$ & & & 5 & 5 & 3 \\
\hline 鉄 & $\mathrm{mg} / \mathrm{L}$ & $<0.05$ & $<0.05$ & $<0.05$ & & & 1 & 2 & 1 \\
\hline クロム & $\mathrm{mg} / \mathrm{L}$ & $<0.02$ & $<0.02$ & $<0.02$ & & & 0.05 & 0.05 & 0.05 \\
\hline カドミウム & $\mathrm{mg} / \mathrm{L}$ & $<0.001$ & $<0.001$ & $<0.001$ & & & 0.01 & 0.01 & 0.003 \\
\hline 鉛 & $\mathrm{mg} / \mathrm{L}$ & $<0.005$ & $<0.005$ & $<0.005$ & & & 0.1 & 0.2 & 0.01 \\
\hline ひ素 & $\mathrm{mg} / \mathrm{L}$ & $<0.005$ & 0.009 & 0.009 & & & 0.1 & 0.1 & 0.01 \\
\hline セレン & $\mathrm{mg} / \mathrm{L}$ & $<0.002$ & $<0.002$ & $<0.002$ & & & 0.02 & 0.02 & 0.01 \\
\hline 水銀 & $\mathrm{mg} / \mathrm{L}$ & $<0.0005$ & $<0.0005$ & $<0.0005$ & & & 0.001 & 0.001 & 0.001 \\
\hline
\end{tabular}


性は経済的に見ても低くはないと考えられる。

実際に石油随伴水処理水を用いて灌溉試験も行 われている（財団法人 国際石油交流センター, 2009）。図 7 は 3 種の牧草を対象として, 随伴水 処理水と水道水による比較試験を行った様子であ る。グラフはポット試験により生育した植物体 の乾燥重量を比較している。この試験では RO 処 理を行わずに吸着処理までの処理水を用いてい る。そのため石油随伴水処理水に若干の塩分（約 $0.5 \%$ ）が含まれるため, 塩分に敏感なアルファ ルファの処理水灌溉時に若干の生育不良が見られ たものの, 他の 2 種類においては顕著な差は見ら れず, 石油随伴水処理水の灌溉が可能であること が示唆されている。

前記したように石油随伴水には高濃度塩分を含 んでいるサイトも存在する。これらの含塩性随伴 水は, 直接植物栽培等の灌溉への適用は困難であ る。また, 塩分濃度 $3 \%$ を超える場合は, 技術的 にも効率的な脱塩による処理水利用は現実的では ない。そのため石油随伴水処理水の適用を進める ためには, この含塩石油随伴水の効果的な利用方 法を検討する必要がある。そこで筆者らは, 昨 今期待の大きい藻類ビジネスへの利用可能性に
ついて検討を行った（財団法人 国際石油交流セ ンター, 2013)。米国エネルギー省（2010）によ ると中東は世界的にも藻類培養に適した地域であ り，その地形と自然環境を生かしたこの新たな産 業の創出が期待されている。公共の微生物コレク ションより入手した既知の藻類や, 中東の特長 のある自然環境の中から単離した塩分に耐え得る 藻類を用いて, 実際の含塩随伴水処理水を用いて 現地屋外での培養試験を行い, 良好な生育が可能 であることを確認している（財団法人国際石油交 流センター, 2012 ; 財団法人国際石油交流セン ター, 2013)。

\section{5. まとめ}

原油の 8 倍量以上と言われるオマーンの石油随 伴水は, 莫大なコストとエネルギーをかけて地下 深層部（約1000m）へ返送されている。また，石 油随伴水の占める割合は, 油田が古くなるほど大 きくなると言われている。一方，オマーンで利用 される水の $90 \%$ 以上は地下水に依存しており, これは GCC 諸国の中でも非常に高い。また，オ マーンの地下水の $55 \%$ が補充の効かない化石水と
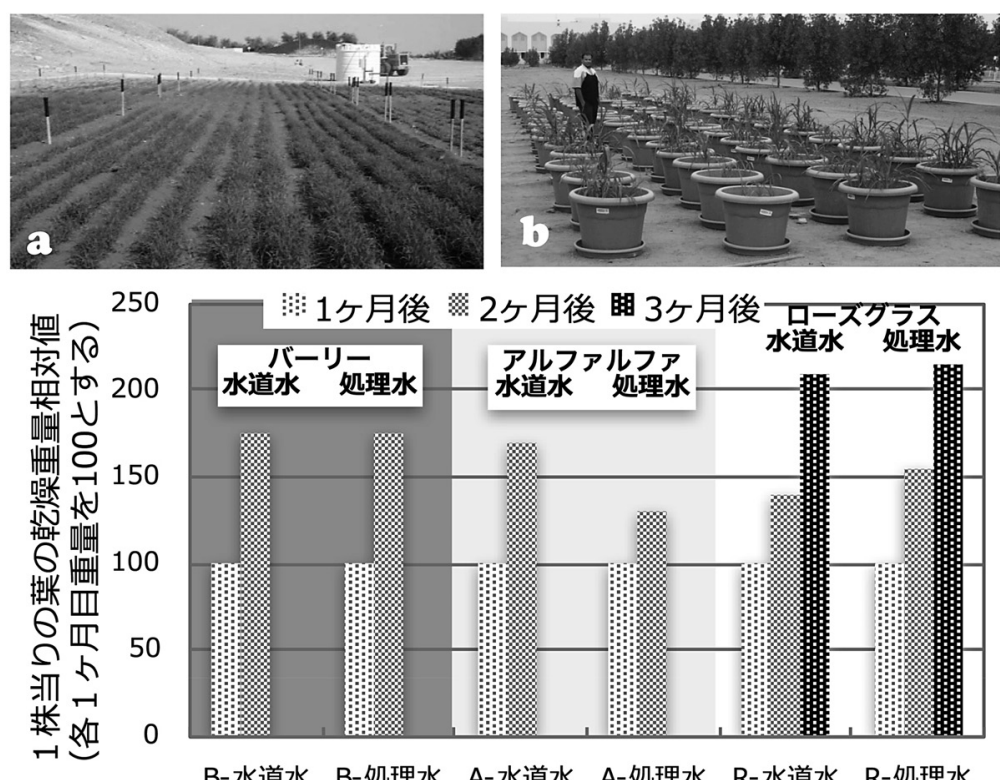

図 7 石油随伴水処理水と水道水による灌溉試験の様子

$a$ : ヤード試験, b : ポット試験, グラフ：ポット試験の結果から得られ た各植物乾燥重量比 
考えられており, 水資源の枯渴が現実的な問題と なっている。そのため, 塩分濃度の低い石油随伴 水を効果的に浄化できれば，オマーンにおける大 きな水資源になり得ると考えられる。

石油随伴水の処理は石油が利用され始めてから 継続的にかかえてきた大きな課題である。処理技 術においては, 我々はとかく最新の制御装置を搭 載した機材を用いて, 処理効率を優先した処理シ ステムを考えがちである。しかし，中東のように 気候や労働条件が特殊な地域の場合, 現地ニーズ を正確に掴み，先方の希望するシステムを実現す ることが重要であった。更に単に処理に留まら ず，当該国の産業の振興に寄与できるスキームを 作成して進めることは, 先方の理解を得やすく, 技術展開もスムーズに行く。

今回紹介した石油随伴水処理システムは, 低コ ス卜排水処理技術（加圧浮上・滤過 ·吸着等）の ベストミックスにより, 汎用性に富み操作が簡易 で高効率なシステムとなっている。さらにこれま で「廃衰物」であり「戻す, 捨てる」ための処理 を行っていた石油随伴水を, 農業生産や藻類培養 への利用性を実証して「新たな水資源」としての 可能性を示したことは, 同国の目指す持続可能産 業の創出に大きく貢献できると考える。

なお筆者らが行った検討は, 一般財団法人国際 石油交流センター（現一般財団法人 JCCP 国際 石油・ガス協力機関）が実施した産油国石油産業 基盤整備事業の一環で行われた一部である。

\section{参考文献}

岡村和夫 ·田崎雅晴・幾島賢治 (2011)：マイク ロバブルを用いた油田随伴水の低コスト処理.

PETROTECH, 34 (11), 787-790.

小島啓輔 - 田崎雅晴 - 岡村和夫 - Mark Sueyoshi ·

Sueyoshi, M. Al-Maamari, R.S. (2014)：ケミカル 圧入法が適用された石油随伴水に対する効果的な 凝集剤の検討及びオマーンにおける連続処理試験. Journal of the Japan Petroleum Institute, 57 (6) , 276286.

小島啓輔 - 田崎雅晴 - 岡村和夫 · Mark Sueyoshi ·

Sueyoshi, M. · Al-Maamari, R.S. (2015)：オマーン に扮ける水資源創出のための石油随伴水利用に関す
るコスト試算. 土木学会論文集 G (環境), 71 (26), 62-72.

財団法人国際石油交流センター（現一般財団法人 JCCP 国際石油・ガス協力機関）（2009）：オマーン 国に扮ける油田随伴水の処理とその利用に関する調 査. 平成20年度産油国石油産業等産業基盤整備事業 報告書.

財団法人国際石油交流センター（現一般財団法人 JCCP 国際石油・ガス協力機関）(2012）：油田随伴 水の処理とその利用に関する技術開発（オマーン） フェーズ II. 平成 23 年度 産油国等石油関連産業基盤 整備・国際共同研究事業報告書.

財団法人国際石油交流センター（現一般財団法人 JCCP 国際石油・ガス協力機関）(2013）：油田随伴 水の処理とその利用に関する技術開発（オマーン） フェーズII. 平成 24 年度 産油国等石油関連産業基盤 整備・国際共同研究事業報告書.

田崎雅晴・岡村和夫（2012）：オマーンにおける石油随 伴水処理一産油国における環境対策一。土木施工, 53 (8)，44-47.

田崎雅晴 - 小島啓輔 - 岡村和夫 (2013a) : 石油随伴水 の COD 測定に扮ける一考察. Journal of the Japan Petroleum Institute, 56 (4), 244-248.

田崎雅晴 - 岡村和夫 - Mark Sueyoshi · Sueyoshi, M.

Al-Maamari, R.S. (2013b) : オマーン国における異な る 3 種の石油随伴 水のパイロットプラント処理試 験. Journal of the Japan Petroleum Institute, 56 (6), 406-413.

独立行政法人石油天然ガス・金属鉱物資源機構（2014）: 石油・天然ガス開発をめぐる技術的な課題. 石油 · 天然ガスレビュー, 48 (1).

濱田秀明 (2013)：石油天然ガス・金属鉱物資源機 構 (JOGMEC) 石油天然ガス資源レポート. http:// oilgas-info.jogmec.go.jp/report_pdf.pl?pdf=1312_out_ h_00_Oman_Resource_trend_2013HPUpload\%2epdf\& id=5043.（2017.09.08閲覧）

Al-Bemani, A., Al-Mazrui, S., Ahmed, M., Escechie, H., Al-Haddabi, M., Al-Khanjari, S., Hirayama, A., Maegaito, M., Kawaguchi, M. and Ishikawa, A. (2001): Omani Oil Fields Produced Water_ Treatment and Utilization, International Symposia on Elemental Sulfur for Agronomic Application and Desert Greening, ESAA \& DG, Abu Dhabi, United Arab Emirates. 
Asada, M., Hirayama, A., Al-Maamari, R.S., Sueyoshi, M., Kawaguchi, M., Ishikawa, A., Maegaito, M., Okamura, K., Al-Bemani, A.S. and Al-Mazrui, S.A. (2007): Feasibility Study on Treatment and Utilization of Oilfield Produced Water in Oman. Proceedings of the 1st Joint QP-JCCP Environment Symposium on Sustainable Development and Climate Change, Doha, Qatar.

Breuer, R. and Grissemann, E. (2011): Produced Water Treatment Using Wetlands- Reducing The Environmental Impact Of Oilfield Operations. Society of Petroleum Engineers, SPE European Health, Safety and Environmental Conference in Oil and Gas Exploration and Production, 22-24 February, Vienna, Austria.

Breuer, R.: Commercial scale produced water treatment using wetlands-reducing the environmental impact of oil field operations. http://www.vetiver.org/ USA_BAUERNimrOman_Article.pdf, Department of Energy, U.S. (2010): National Algae Biofuels Technology Roadmap (Final). (2017.09.07閲覧)

Fakhru'sl-Razi, A., Pendashteh, A., Abdullah, L.C., Biak, D.R., Madaeni, S.S. and Abidin, Z.Z. (2009): Review of technologies for oil and gas produced water treatment. Journal of Hazardous Materials, 170, 530-551.

Igunnu, E.T. and Chen, G.Z. (2012): Produced water treatment technologies. International Journal of LowCarbon Technologies, 9 (3), 157-177.

Ma, B., Gao and B., Yue, Q. (2013): Study on emulsification stability of wastewater produced by polymer flooding. J. Petrol. Sci. Eng., 110, 27.

(受付：2017年 7 月12日，受理：2017年11月16日） 